Egyptian J. Anim. Prod. (2001) 38(1):1-14.

\title{
ESTIMATION OF CROSSBREEDING COMPONENTS FOR SOME LIFETIME TRAITS IN UP-GRADING TRIALS OF DOMIATI CATTLE WITH THREE DAIRY BREEDS IN EGYPT
}

\author{
E.A. Afifi ${ }^{1}$, M.H. Khalil ${ }^{2}$ and Samira A. Arafa ${ }^{3}$ \\ 1-Department of Animal Production, Faculty of Agriculture at Moshtohor, \\ Zagazig University, Egypt, 2- Department of Animal Production and Breeding, \\ College of Agriculture and Veterinary Medicine, King Saud University, Qassim, \\ Burieda, P.O. Box, 1842, Kingdom of Saudi Arabia. 3-Animal Production \\ Research Institute, Ministry of Agriculture, Dokki, Cairo, Egypt
}

\section{SUMMARY}

Lifetime traits in three up-grading trials of local Domiati with Friesian (Friesian trial), Shorthorn (Shorthorn trial) and Jersey (Jersey trial) were genetically evaluated. Direct $\left(G^{\prime}\right)$ and maternal $\left(G^{M}\right)$ additive effects, direct $\left(H^{\prime}\right)$ and maternal $\left(H^{M}\right)$ heterotic effects and direct $\left(R^{\prime}\right)$ and maternal $\left(R^{M}\right)$ recombination effects for total kilograms born (TKB), number of calvings $(N C)$, herd life (HL), length of productive life (LPL), TKB/HL and TKB/LPL were estimated. In Friesian and Shorthorn trials, upgrades generally showed the highest means for TKB, NC, HL and $L P L$ relative to the two parental purebreds, but in Jersey trial, upgrades showed higher means than local Domiati only. In Friesian trial, TKB/LPL and TKB/HL decreased with the increase of Friesian genes, while, no clear trend was detected for the same traits in Shorthorn and Jersey trials. In the three trials, estimates of $G^{\prime}$ for all lifetime traits were generally in favour of the European breeds, except for $T K B / L P L$. In Friesian and Jersey trials, estimates of $G^{M}$ were negative and in favour of the European breeds, while the estimates recorded in Shorthorn trial were positive and in favour of local Domiati. Estimates of $H^{\prime}$ recorded for all traits in Friesian and Shorthorn trials were positive, while the estimates recorded in Jersey trial were negative. In Friesian trial, estimates of $H^{\prime}$ were $43.2 \%$ for TKB, $36.8 \%$ for $N C, 8.7 \%$ for $H L, 17.7 \%$ for $L P L, 43.3 \%$ for TKB/HL and $19.3 \%$ for TKB/LPL, while they were $21.3 \%, 18.99 \%, 13.6 \%, 21.8 \%, 14.1 \%$ and $0.79 \%$ in the Shorthorn trial in the same order. Estimates of $H^{M}$ in the three trials were positive and ranged from $2.1 \%$ to $44.1 \%$. Estimates of $R^{\prime}$ were also positive in the three trials, white those of $R^{M}$ were positive in Friesian trial and negative in Shorthorn and Jersey trials.

Keywords: Egyptian Domiati cows,up-grading, lifetime traits, additive, heterotic and recombination effects 
Afifi et al.

\section{INTRODUCTION}

Beef from dairy cattle in Egypt is obtained from bull calves beyond the veal stage in addition to young and old cows or bulls culled from the breeding stock of dairy herds after being fattened.

Up-grading Egyptian Domiati cattle with some foreign breeds of dairy cattle was performed to improve milk production (Arafa et $\mathrm{al} .$, 1998) and to increase meat production, since it was shown that crossbred dams give calves with heavier birth weight than straightbred ones (Gregory et al., 1985; Elzo et al., 1990; Cundiff et al,, 1992; Thorpe et al., 1993). Many investigators found that body weight of the calf at birth was strongly correlated with its weight at later ages (Gregory et al., 1985; Arthur et al., 1989; Cundiff et al., 1992; Thorpe et al., 1993). Thus, total kilograms born by the cow during her productive life form an important component in beef production. The other lifetime traits represented by number of calvings during the productive life of the cow along with length of productive life and herd life of the cow are also of considerable importance in this concern.

Three trials of upgrading of Egyptian Domiati cows with Friesian, dairy Shorthorn and Jersey bulls were carried out in the Ministry of Agriculture in Egypt. The objective of the present study was to estimate the genetic components of direct additive $\left(\mathrm{G}^{\mathrm{l}}\right)$, maternal additive $\left(\mathrm{G}^{\mathrm{M}}\right)$, direct heterosis $\left(\mathrm{H}^{\mathrm{l}}\right)$, maternal heterosis $\left(\mathrm{H}^{\mathrm{M}}\right)$, direct recombination effect $\left(\mathrm{R}^{\mathrm{I}}\right)$ and maternal recombination effect $\left(\mathrm{R}^{\mathrm{M}}\right)$ for lifetime traits in these up-grading trials conducted in Egypt.

\section{MATERIALS AND METHODS}

Herds

Animals of three dairy herds in three experimental stations located at ElGimmaiza (Mid-Delta), El-Serw (North Delta) and Sids (Mid-Egypt) were used in this work. The three stations belong to the Animal Production Research Institute (APRI), Agricultural Research Center, Ministry of Agriculture, Egypt. Local Domiati (D) cattle were upgraded with Friesian (F) in El-Gimmaiza station (called Friesian trial); dairy Shorthorn (S) in El-Serw station (called Shorthorn trial) and Jersey $(J)$ in Sids station (called Jersey trial) up to 15/16 European blood. In Friesian and Shorthorn trials only, inter-se matings $7 / 8$ European blood (F or $S$ ) were obtained. Domiati, European and crossbred animals of the three up-grading trials of the study were kept under similar conditions of housing and management organized by APRI. Calvings during the period of SeptemberNovember, December-February, March-May and June-August were classified as autumn, winter, spring and summer calvings, respectively. During the winter and spring (i.e. during the period of keeping animals on the open fields of Egyptian clover), females of each breeding group were tethered in the field in a specific area. They were checked for estrus twice daily by the assigned bull and served when they were in heat at the proper time. Pregnancy diagnosis was done 60 days post service and females that failed to conceive were left with the same bull to be mated and so on. During summer and autumn (i.e. the period of keeping animals in open sheds), females were divided into mating groups and each group was housed with the assigned bull in one shed for two months. Pregnancy was diagnosed by rectal palpation. 


\section{Data collection and adjustments}

Data were available on 2754, 1953 and 986 normal lactation records in Friesian, dairy Shorthorn and Jersey trials, respectively. Birth weights of the calves of many cows were not available. Also, only cows that had at least three calvings are included in the analysis. Data used in the present study were collected over a period of 20 consecutive years started in 1960. Table 1 shows the distribution of lactation records and cows in the three trials. The numbers of cows used in the analysis were 222,101 and 105 in Friesian, Shorthorn and Jersey trials, respectively. Records of cows in each upgrading trial were edited in a separate file for statistical analysis. Within each trial, information on each cow included cow number, birth date, breed group of the cow, parity number, calving date (birth date of the calf), age at calving, and birth weight of the born calf and its sex. Sires and dams of the cows were not recorded or identified in most cases. In all trials, lifetime traits included total kilograms born during the productive life of the cow (TKB), number of calvings per cow (NC), herd life (HL) and length of productive life (LPL). Herd life was defined as the period from birth of the cow to her natural disposal, while length of productive life was defined as the period from the first calving to disposal (due to diseases, reproductive problems, accidents or natural death). TKB/HL and TKB/LPL were defined as TKB per month of herd life and TKB per month of productive life, respectively.

Table 1. Distribution of records in the three trials

\begin{tabular}{lccc}
\hline Item & \multicolumn{3}{c}{ Trial } \\
\cline { 2 - 4 } & Friesian & Shorthorn & Jersey \\
\hline Number of cows & 222 & 101 & 105 \\
Total number of lactation records & 1555 & 621 & 695 \\
At least three calvings per cow & 1114 & 508 & 591 \\
Number of cows in different genetic groups: & & & \\
Domiati (D) & 15 & 40 & 1 \\
European (E) & 84 & 27 & 10 \\
& 16 & -- & 2 \\
& 39 & 2 & 30 \\
$7 / 8 \mathrm{E} 1 / 8 \mathrm{D}$ & 36 & 2 & 39 \\
15/16E1/16D & 13 & 4 & 23 \\
$(3 / 4 \mathrm{E} 1 / 4 \mathrm{D})^{2}$ & 12 & 13 & \\
$(7 / 8 \mathrm{E} 1 / 8 \mathrm{D})^{2}$ & 7 & 13 & \\
\hline
\end{tabular}

Using the mixed model program of Harvey (1990), birth weight of the calf (as a trait of the cow) across all parities of each trial was analyzed for the effects of breed group of the cow, cow within breed group, year-season combination, parity and sex 
(named model 1). Then, data of birth weight were corrected for the effects of yearseason of calving, parity and sex. The corrected data of birth weight were used to calculate total kilograms born by each cow during her productive life. Data of TKB, NC, HL, LPL, TKB/HL and TKB/LPL were analysed for the effects of breed group, year of birth of the cow and season of her birth (named model 2).

\section{Estimation of crossbreeding components}

Effects of direct additive $\left(\mathrm{G}^{\mathrm{l}}\right)$, maternal additive $\left(\mathrm{G}^{\mathrm{M}}\right)$, direct heterosis $\left(\mathrm{H}^{\mathrm{l}}\right)$, maternal heterosis $\left(\mathrm{H}^{\mathrm{M}}\right)$, direct recombination effect $\left(\mathrm{R}^{\mathrm{l}}\right)$ and maternal recombination effect $\left(\mathrm{R}^{\mathrm{M}}\right)$ were estimated according to Dickerson (1992). Model 2 mentioned above was used to drive a selected set of linear contrasts, i.e, $G^{\mathrm{I}}, \mathrm{G}^{\mathrm{M}}, \mathrm{H}^{\mathrm{I}}, \mathrm{H}^{\mathrm{M}}, \mathrm{R}^{\mathrm{I}}$ and $\mathrm{R}^{\mathrm{M}}$. The coefficients required to estimate the contrasts of individual additive $\left(G^{\prime}\right)$ and maternal additive $\left(\mathrm{G}^{\mathrm{M}}\right)$ effects were calculated as the deviation of Domiati $\left(\mathrm{g}_{\mathrm{D}}^{\mathrm{I}}\right)$ minus European $\left(g_{E}^{1}\right)$, i.e. $G^{1}=g_{D}{ }_{D}-g_{E}^{1}$ and $G^{M}=g_{D}^{M}-g_{E}^{M}$; where $g_{D}^{I}, g_{E}^{I}, g_{D}^{M}$ and $g_{E}^{M}$ represent the Domiati and European additive genetic breed effects in the individual (I) and the dam (M), respectively. According to Van der Werf and de Boer (1989a), the coefficients for individual $\left(\mathrm{H}^{\mathrm{l}}\right)$ and maternal $\left(\mathrm{H}^{\mathrm{M}}\right)$ heterosis were calculated for the daughter and the dam, respectively, as: $[\operatorname{Ps}(1-\operatorname{Pd})+\operatorname{Pd}(1-\operatorname{Ps})]$. According to Van der Werf and de Boer (1989b), the coefficients for recombination effect (individual and maternal) were calculated as: $[\mathrm{Ps}(1-\mathrm{Ps})+\mathrm{Pd}(1-\mathrm{Pd})]$; where $\mathrm{Ps}$ $=$ fraction of sire genes and $\mathrm{Pd}=$ fraction of dam genes. The coefficients for expected genetic contribution in different genetic groups computed according to Dickerson (1992) are presented in Table 2.

\section{RESULTS AND DISCUSSION}

In Friesian trial, genetic group differences were only significant $(\mathrm{P}<0.05$ or $\mathrm{P}<0.001)$ for $\mathrm{TKB}$ and $\mathrm{TKB} / \mathrm{HL}$. In Shorthorn trial, genetic group differences were not significant for all traits studied. For all lifetime traits in Jersey trial, significant differences $(\mathrm{P}<0.05)$ between genetic groups were detected only for $\mathrm{NC}$.

\section{Genetic-group comparison within each up-grading trial}

Performances in all lifetime traits (TKB, NC, HL and LPL) of each upgrade in Friesian and Shorthorn trials were generally higher than those of the two purebreds, but in Jersey trial, upgrades showed better performance than only the local Domiati (Figures 1 up to 4). Also, performance of $1 / 2 \mathrm{~F} 1 / 2 \mathrm{D}$ group in Friesian trial recorded the highest means for TKB and NC compared to the other upgrades. In Shorthorn trial, 3/4S I/4D recorded the highest means for all traits studied compared to the other upgrades. Upgrades in the present study generally showed the highest crops of calves along with the longest life to lactate and reproduce relative to the two parental purebreds (Figures 1 up to 4). For the same three trials of upgrading, Arafa (1987\& 1996) also reported the superiority of upgrades relative to the two purebreds particularly upgrading of Domiati with Shorthorn for lactation traits. In Friesian trial, TKB/LPL and TKB/HL decreased with the increase of Friesian genes, while, no clear trend was detected for the same two traits in Shorthorn and Jersey trials (Figures $5 \& 6)$. 
Egyptian J. Anim. Prod. (2001)

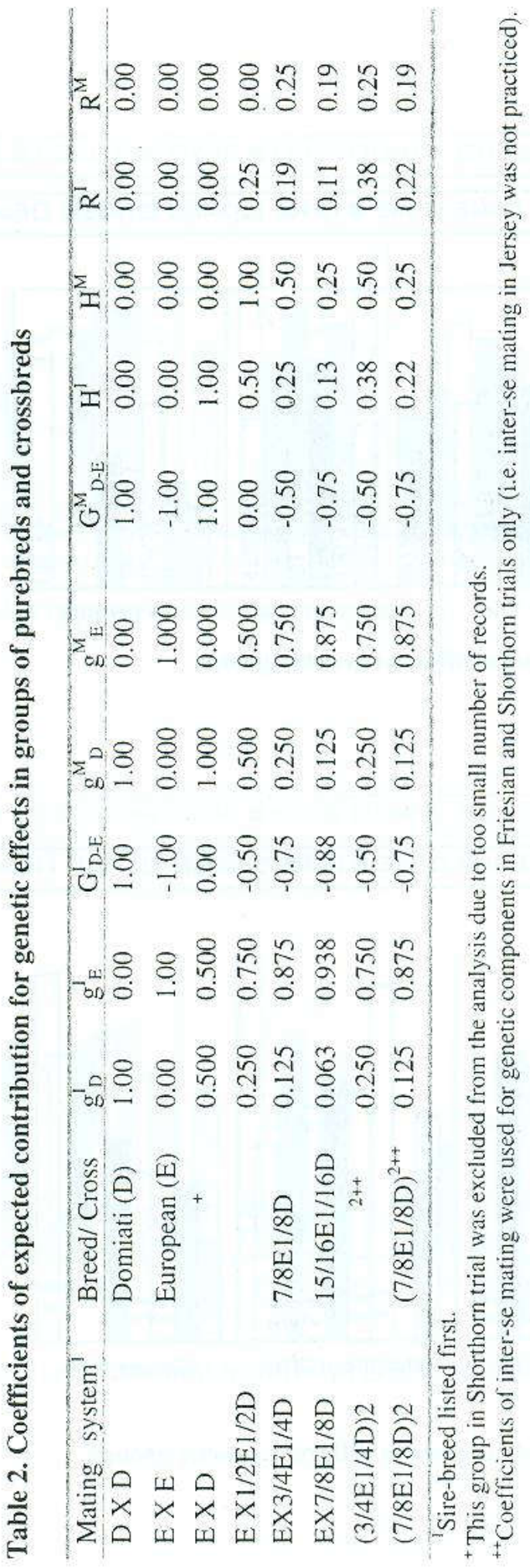




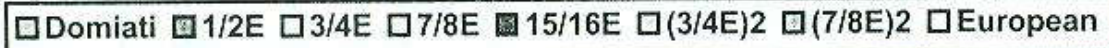

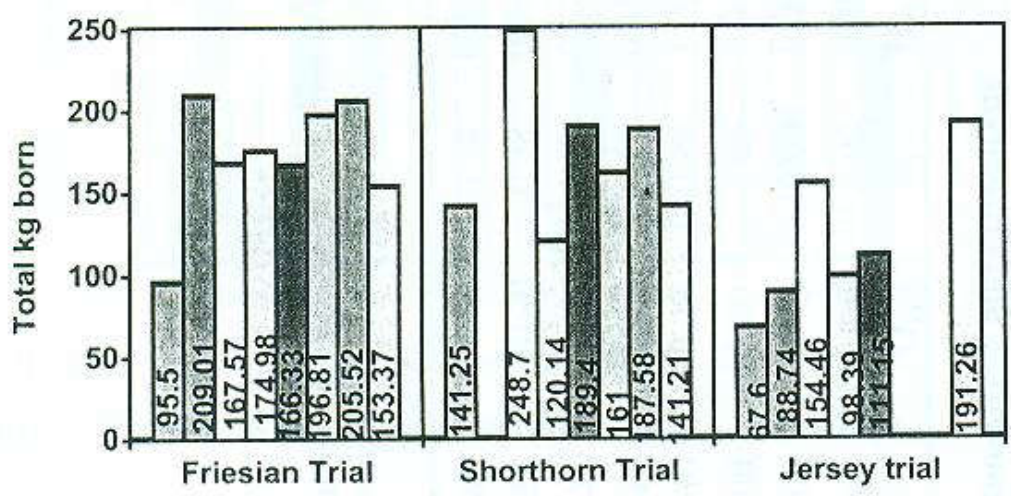

Figure 1: Total kg born in different genetic groups

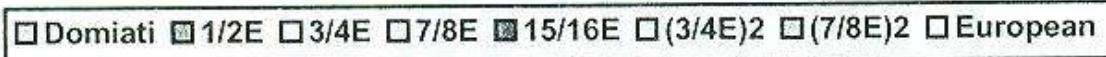

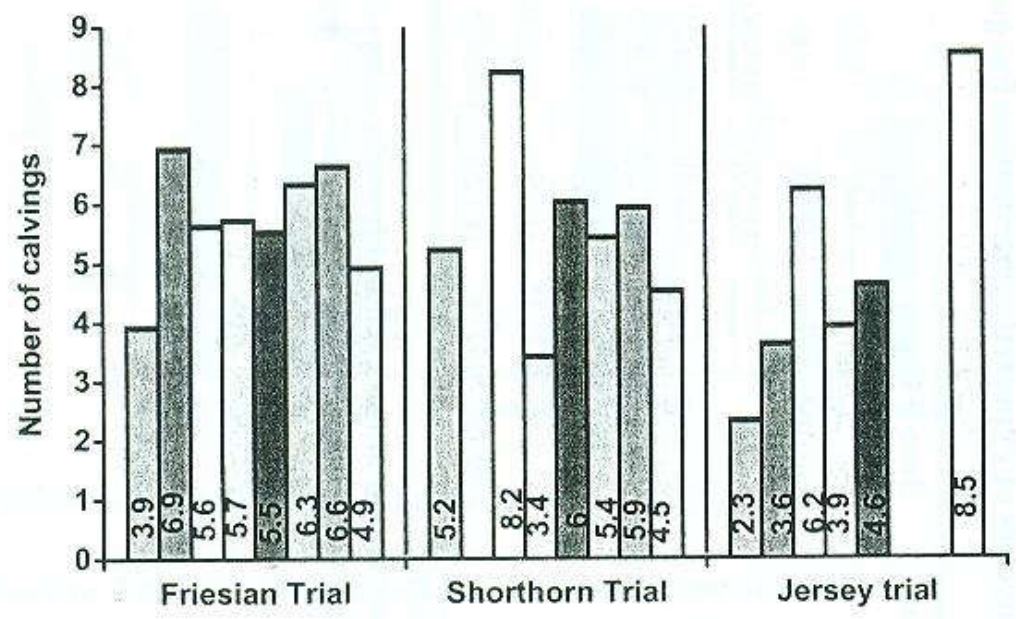

Figure 2: Number of calvings in different genetic groups 
$\square$ Domiati $\square 1 / 2 \mathrm{E} \square 3 / 4 \mathrm{E} \square 7 / 8 \mathrm{E}$ 圆 15/16E $\square(3 / 4 \mathrm{E}) 2 \square(7 / 8 \mathrm{E}) 2$ European

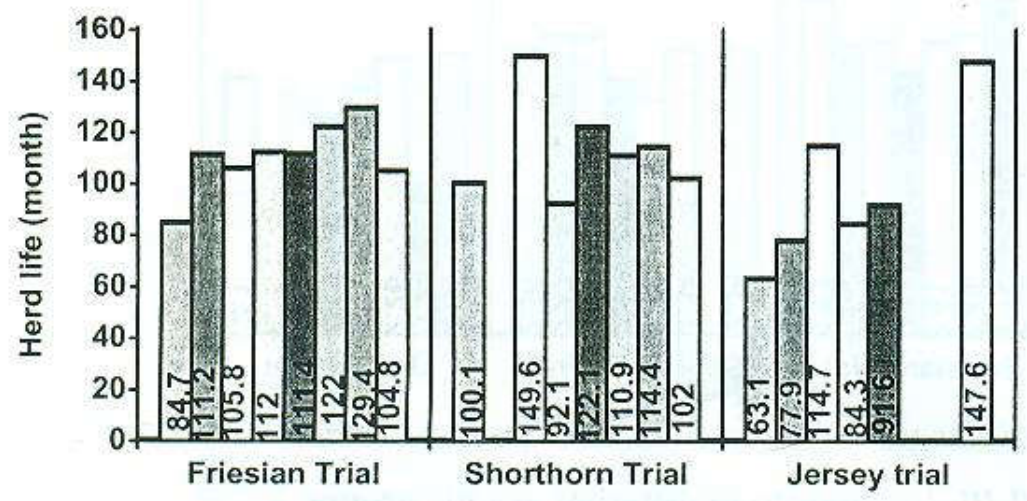

Figure 3: Herd life (month) in different genetic groups

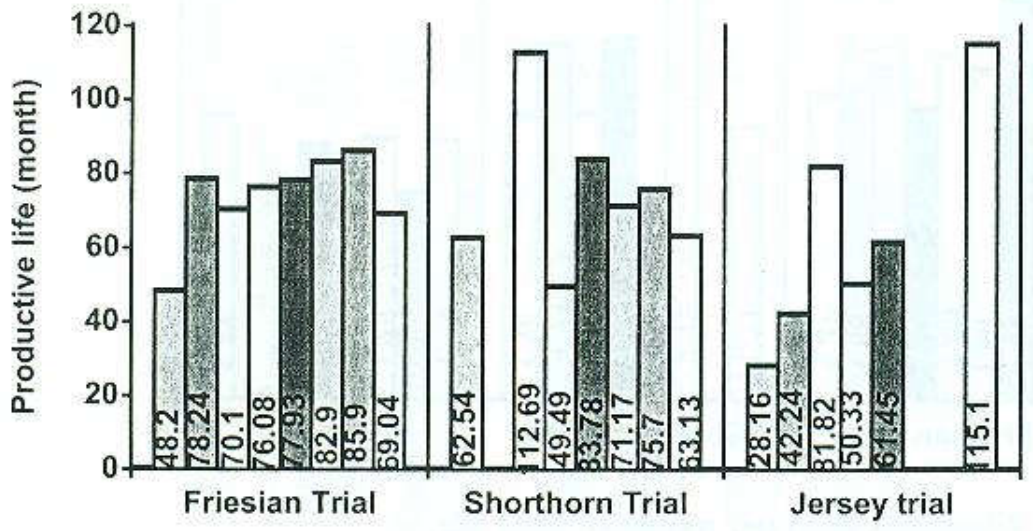

Figure 4: Productive life (month) in different genetic groups 
$\square$ Domiati $\square$ 1/2E $\square 3 / 4 \mathrm{E} \square 7 / 8 \mathrm{E}$ 圆15/16E $\square(3 / 4 \mathrm{E}) 2 \mathrm{Q}(7 / 8 \mathrm{E}) 2$ European

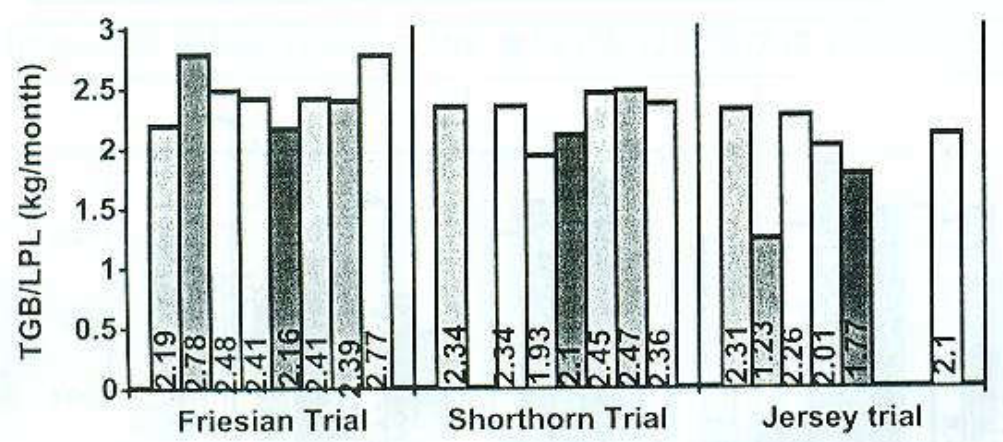

$\mathrm{TKB} / \mathrm{LPL}=$ total kilograms born per month of productive life.

Figure 5: TKB/LPL (kg/month) in different genetic groups

$\square$ Domiati $\square 1 / 2 \mathrm{E} \square 3 / 4 \mathrm{E} \square 7 / 8 \mathrm{E}$ 圆15/16E $\square(3 / 4 \mathrm{E}) 2 \square(7 / 8 \mathrm{E}) 2$ European

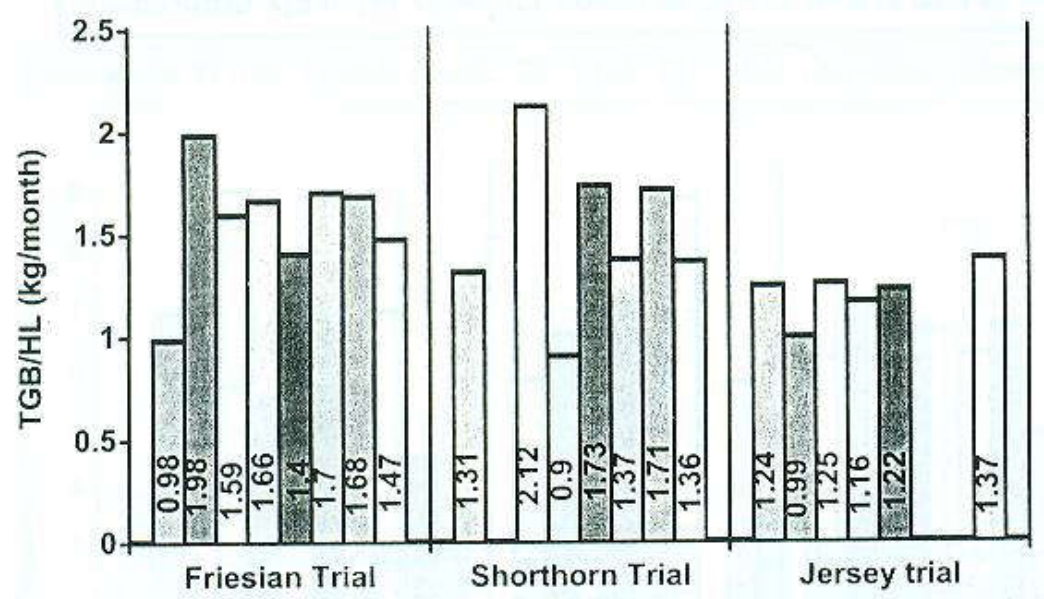

$\mathrm{TKB} / \mathrm{HL}=$ total kilograms born per month of herd life.

Figure 6: TKB/HL (kg/month) in different genetic groups 


\section{Direct $\left(\mathbf{G}^{\mathrm{I}}\right)$ and maternal $\left(\mathbf{G}^{\mathrm{M}}\right)$ additive effects}

In the three up-grading trials, estimates of direct additive effect $\left(G^{I}=g_{D}^{I}-g_{E}^{I}\right)$ for all lifetime traits were negative (except TKB/LPL) and in favour of the European (E) breeds (Table 3). Arafa (1996) and Arafa et al (1998) came to the same conclusion for milk production traits and reproductive performance in the same three upgrading trials. Estimates of $\mathrm{G}^{\mathrm{l}}$ were significant $(\mathrm{P}<0.05)$ for all traits except $\mathrm{NC}$ and TKB/LPL in Friesian trial, non-significant in Shorthorn and Jersey trials (Table 3). Significant estimate of $\mathrm{G}^{\mathrm{I}}$ for birth weight was reported by Dillard et al. (1980), Trail et al. (1982), Koch et al. (1985) and Olson et al (1985) working on different breeds of beef cattle. In Egypt, Arafa (1996) with three trials of upgrading and Khalil et al. (2000) with three crossbreeding trials of Holstein cattle with German Friesian also reported significant additive $\left(\mathrm{G}^{\mathrm{l}}\right)$ effects in milk production traits $(\mathrm{P}<0.001)$.

Table 3. Estimates of direct $\left(\mathrm{G}^{\mathrm{I}}\right)$ and maternal $\left(\mathrm{G}^{\mathrm{M}}\right)$ additive effects and their standard errors (SE) for lifetime traits in the three up-grading trials

\begin{tabular}{|c|c|c|c|c|c|c|}
\hline \multirow{2}{*}{ Trait $^{+}$} & \multicolumn{2}{|c|}{ Friesian trial } & \multicolumn{2}{|c|}{ Shorthorn trial } & \multicolumn{2}{|c|}{ Jersey trial } \\
\hline & Estimate & SE & Estimate & $\mathrm{SE}$ & Estimate & $\mathrm{SE}$ \\
\hline \multicolumn{7}{|c|}{ Direct additive effect: } \\
\hline TKB & $-93.32 *$ & 43.99 & -28.02 & 23.26 & -119.88 & 124.65 \\
\hline $\mathrm{NC}$ & -1.89 & 1.35 & 0.21 & 0.83 & -5.95 & 4.49 \\
\hline HL & $-40.45 \%$ & 17.39 & -12.37 & 11.12 & -80.08 & 74.07 \\
\hline LPL & $-38.44 *$ & 17.49 & -9.77 & 11.39 & -85.08 & 74.93 \\
\hline TKB/LPL & 0.03 & 0.28 & 0.15 & 0.27 & 0.15 & 1.90 \\
\hline TKB/HL & $-0.62 *$ & 0.28 & -.21 & 0.24 & -0.13 & 0.52 \\
\hline \multicolumn{7}{|c|}{ Maternal additive effect: } \\
\hline TKB & -56.91 & 58.90 & 1.48 & 30.30 & -137.83 & 125.17 \\
\hline NC & -0.73 & 1.81 & 1.07 & 1.07 & -6.81 & 4.90 \\
\hline $\mathrm{HL}$ & -40.96 & 23.29 & 1.87 & 14.49 & $-93,35$ & 74.38 \\
\hline LPL & -34.33 & 23.42 & 4.65 & 14.84 & -100.14 & 75.24 \\
\hline TKB/LPL & 0.45 & 0.37 & 0.07 & 0.36 & -0.41 & 1.91 \\
\hline TKB/HL & -0.17 & 0.37 & -0.02 & 0.31 & -0.34 & 0.53 \\
\hline
\end{tabular}

$+\mathrm{TKB}=$ total kilograms born, $\mathrm{NC}=$ number of calvings, $\mathrm{HL}=$ herd life in months,

$\mathrm{LPL}=$ length of productive life in months, TKB/HL=total kilograms born per month of herd life and $\mathrm{TKB} / \mathrm{LPL}=$ total kilogrms born per month of productive life.

$*=\mathrm{P}<0.05$.

The estimates of maternal additive effect $\left(G^{\mathrm{M}}=\mathrm{g}^{\mathrm{M}}{ }_{\mathrm{D}} \mathrm{g}^{\mathrm{M}} \mathrm{E}\right)$ were non-significant and negative for most of the traits, i.e. in favour of the European breeds in Friesian and Jersey trials (Table 3). In Shorthorn trial, positive estimates for all traits were obtained except for TKB/HL, i.e. in favour of the Domiati. Arafa (1996) also recorded negative estimates of $\mathrm{G}^{\mathrm{M}}$ for milk traits in favour to the European breeds of dams. 


\section{Direct $\left(\mathrm{H}^{\mathrm{I}}\right)$ and maternal $\left(\mathbf{H}^{\mathrm{M}}\right)$ heterosis}

Estimates of direct heterosis $\left(\mathrm{H}^{1}\right)$ in Friesian and Shorthorn trials for all lifetime traits were positive (Table 4). The estimates of $\mathrm{H}^{\prime}$ ranged from 8.7 to $43.3 \%$ in Friesian trial and from 0.79 to $21.8 \%$ in Shorthorn trial. These positive estimates of $\mathrm{H}^{\mathrm{I}}$ show that upgrading Egyptian Domiati cows with Friesian and Shorthorn bulls would improve the performance of lifetime traits. In agreement with these results, Koch et al. (1985), Reimer et al. (1985), Hohenboken and Webet (1989), Gregory et al. (1991) and Thorpe et al. (1993) found positive estimates of $\mathrm{H}^{\mathrm{T}}$ for birth weight. Contrary to what was found in Friesian and Shorthorn trials, estimates of $\mathrm{H}^{1}$ for lifetime traits were negative in Jersey trial (Table 4). In this respect, Wessely et al. (1986) found that crossing Holstein Friesian breed with German Black Pied was responsible for a reduction in the calf birth weight, amounting tol0\% of the parental mean. Also, negative estimates of $\mathrm{H}^{\mathrm{I}}$ were recorded by Khalil et al. (2000) for milk yield traits (90-day, 305-day and total) in three crossbreeding trials of Holstein cattle with German Friesian raised in Egypt.

Table 4. Estimates of direct $\left(\mathbf{H}^{\mathrm{I}}\right)$ and maternal $\left(\mathbf{H}^{\mathrm{M}}\right)$ heterosis and their standard errors (SE) for lifetime traits in the three up-grading trials

\begin{tabular}{|c|c|c|c|c|c|c|c|c|c|}
\hline \multirow[b]{2}{*}{ Trait $^{+}$} & \multicolumn{3}{|c|}{ Friesian trial } & \multicolumn{3}{|c|}{ Shorthorn trial } & \multicolumn{3}{|c|}{ lersey [rial } \\
\hline & $\begin{array}{l}\text { Estimate } \\
\text { (in units) }\end{array}$ & SE & $\begin{array}{l}\text { Estimate } \\
\text { (in \%) }\end{array}$ & $\begin{array}{l}\text { Estimate } \\
\text { (in units) }\end{array}$ & SE & $\begin{array}{l}\text { Estimate } \\
\text { (in \%) }\end{array}$ & $\begin{array}{l}\text { Estimate } \\
\text { (in units) }\end{array}$ & $\mathrm{SE}$ & $\begin{array}{l}\text { Estimate } \\
\qquad(\text { in } \%)^{++}\end{array}$ \\
\hline \multicolumn{10}{|c|}{ Direct heterosis: } \\
\hline TKB & $53.7^{* ;:=}$ & 19.6 & 43.2 & 30.0 & 18.5 & 21.3 & -17.9 & 61.5 & -13.8 \\
\hline $\mathrm{NC}$ & $1.62^{* *}$ & 0.60 & 36.8 & 0.92 & 0.66 & 18.99 & -0.87 & 2.41 & -16.03 \\
\hline $\mathrm{HL}$ & 8.2 & 7.8 & 8.7 & 13.73 & 8.9 & 13.6 & -13.3 & 36.0 & -12.6 \\
\hline LPL & 10.4 & 7.8 & 17.7 & 13.68 & 9.1 & 21.8 & -15.1 & 37.0 & -21.03 \\
\hline TKB/LPL & $0.43^{2 * \cos x}$ & 0.1 & 19.3 & 0.02 & 0.22 & 0.79 & -0.56 & 0.94 & -25.6 \\
\hline TKB/HL & $0.53^{* * * *}$ & 0.1 & 43.3 & 0.19 & 0.19 & 14.1 & -0.21 & 0.26 & -15.8 \\
\hline \multicolumn{10}{|c|}{ Maternal heterosis: } \\
\hline TKB & 18.6 & 15.3 & 14.9 & 58.77 & 39.3 & 41.6 & 23.9 & 39.7 & 18.4 \\
\hline $\mathrm{NC}$ & 0.46 & 0.47 & 10.5 & 1.78 & 1.40 & 36.7 & 0.84 & 1.55 & 15.5 \\
\hline $\mathrm{HL}$ & 7.6 & 6.1 & 7.97 & 27.71 & 18.8 & 27.4 & 10.8 & 23.6 & 10.2 \\
\hline LPL & 6.6 & 6.1 & 11.2 & 27.66 & 19.3 & 44.1 & 11.8 & 23.9 & 16.5 \\
\hline TKB/LPL & 0.06 & 0.1 & 2.7 & -0.04 & 0.46 & -1.71 & 0.30 & 0.60 & 13.5 \\
\hline TKB/HL & 0.15 & 0.1 & 12.2 & 0.37 & 0.40 & 27.5 & 0.03 & 0.17 & 2.1 \\
\hline
\end{tabular}

Positive but non-significant estimates of $\mathrm{H}^{\mathrm{M}}$ were recorded for all lifetime traits in the three trials, except for TKB/LPL in Shorthorn trial (Table 4). The estimates ranged from 2.7 to $14.9 \%$ in Friesian trial, from 27.4 to $44.1 \%$ in Shorthorn trial and from 2.1 to $18.4 \%$ in Jersey trial. In general, these positive estimates of $\mathrm{H}^{\mathrm{M}}$ indicate that cows born from crossbred dams showed better performance for lifetime traits than cows born from straightbred dams. The high estimates of $\mathrm{H}^{\mathrm{M}}$ for all lifetime traits in Shorthorn trial indicate that daughters born from crossbred dams including 
Shorthorn blood could perform better in lifetime traits studied than daughters born from purebred dams.

\section{Direct $\left(\mathbf{R}^{\mathrm{I}}\right)$ and maternal $\left(\mathrm{R}^{\mathrm{M}}\right)$ recombination effects}

Estimates of $\mathrm{R}^{1}$ were positive and non-significant for all lifetime traits in the three trials (Table 5). Estimates of $\mathrm{R}^{\mathrm{I}}$ for all lifetime traits in Friesian and Shorthorn trials are generally lower than estimates of $\mathrm{H}^{\mathrm{I}}$ and this implies that dominance effect was positive. However, heterosis was assumed to represent dominance effect plus half of the additive by additive effect, whereas the recombination effects represent half of the additive by additive effect (Van der Werf and de Boer, 1989a\&b). In Jersey trial, estimates of $\mathrm{H}^{\mathrm{I}}$ were negative and lower than estimates of $\mathrm{R}^{\mathrm{I}}$, which implies that epistatic effect is more important.

Table 5. Estimates of direct $\left(\mathbb{R}^{\mathrm{I}}\right)$ and maternal $\left(\mathbf{R}^{\mathrm{M}}\right)$ recombination effects and their standard errors (SE) for lifetime traits in the three upgrading trials

\begin{tabular}{|c|c|c|c|c|c|c|}
\hline \multirow{2}{*}{ Trait ${ }^{*}$} & \multicolumn{2}{|c|}{ Friesian trial } & \multicolumn{2}{|c|}{ Shorthorn trial } & \multicolumn{2}{|c|}{ Jersey trial } \\
\hline & Estimate & $\mathrm{SE}$ & Estimate & $\mathrm{SE}$ & Estimate & SE \\
\hline \multicolumn{7}{|c|}{ Direct recombination effect: } \\
\hline TKB & 16.63 & 11.13 & 12.90 & 8.00 & 4.31 & 11.99 \\
\hline $\mathrm{NC}$ & 0.42 & 0.34 & 0.37 & 0.28 & 0.14 & 0.47 \\
\hline HL & 8.10 & 4.43 & 5.65 & 3.83 & 1.66 & 7.12 \\
\hline LPL & 6.34 & 4.40 & 5.31 & 3.92 & 2.03 & 7.21 \\
\hline TKB/LPL & 0.01 & 0.07 & 0.03 & 0.09 & 0.070 & 0.18 \\
\hline $\mathrm{TKB} / \mathrm{HL}$ & 0.09 & 0.07 & 0.06 & 0.08 & 0.005 & 0.05 \\
\hline \multicolumn{7}{|c|}{ Maternal recombination effect: } \\
\hline TKB & 13.00 & 8.73 & -7.60 & 8.78 & -6.47 & 9.73 \\
\hline $\mathrm{NC}$ & 0.31 & 0.27 & -0.38 & 0.31 & -0.28 & 0.38 \\
\hline $\mathrm{HL}$ & $7.28 *$ & 3.45 & -3.79 & 4.20 & -4.00 & 5.78 \\
\hline LPL & 6.12 & 3.47 & -4.72 & 4.30 & -3.54 & 5.85 \\
\hline TKB/LPL & -0.03 & 0.05 & -0.05 & 0.10 & -0.018 & 0.148 \\
\hline $\mathrm{TKB} / \mathrm{HL}$ & 0.06 & 0.06 & -0.10 & 0.09 & -0.008 & 0.041 \\
\hline
\end{tabular}

${ }^{+} \mathrm{TKB}=$ total kilograms born, $\mathrm{NC}=$ number of calvings, $\mathrm{HL}=$ herd life in months,

$\mathrm{LPL}=$ length of productive life in months, $\mathrm{TKB} / \mathrm{HL}=$ total kilograms born per month of herd life and $\mathrm{TKB} / \mathrm{LPL}=$ total kilogrms born per month of productive life.

$*=\mathrm{P}<0.05$.

Estimates of $\mathrm{R}^{\mathrm{M}}$ for all lifetime traits in Friesian trial were positive, with significant effect $(\mathrm{P}<0.05)$ on $\mathrm{HL}$ (Table 5). Positive and significant $\mathrm{R}^{\mathrm{M}}$ for $\mathrm{HL}$ indicates that crossbred dams including Friesian genes mothered cows with longer herd life than did purebred Friesian dams when both groups were mated to the same purebred Friesian bulls. Estimates of $\mathrm{R}^{\mathrm{M}}$ for all lifetime traits were negative and nonsignificant in Shorthorn and Jersey trials (Table 5). The non-significant effect of $\mathrm{R}^{\mathrm{M}}$ shows that epistatic effect appeared to have little influence on lifetime traits. On the other hand, estimates of $\mathrm{R}^{\mathrm{M}}$ for most lifetime traits were smaller than estimates of $\mathrm{H}^{\mathrm{M}}$, which show that the dominance effects on these traits were positive and relatively more important than the epistatic effect. 


\section{CONCLUSIONS}

(1) Grades of inter-se matings [i.e. $(3 / 4 \mathrm{~F} 1 / 4 \mathrm{D})^{2}$ or $(7 / 8 \mathrm{~F} 1 / 8 \mathrm{D})^{2}$ or $(3 / 4 \mathrm{~S} 1 / 4 \mathrm{D})^{2}$ or $\left.(7 / 8 \mathrm{~S} 1 / 8 \mathrm{D})^{2}\right]$ showed better performance in lifetime traits when compared to the exotic paternal purebreds (Friesian and Shorthorn).

(2) Superiority of European breeds (Friesian, Shorthorn and Jersey) over Domiati in their direct and maternal additivity for most lifetime traits indicates that these breeds could be used as effective breeds in dairy industry in Egypt to improve calf crop and to increase the longevity of cows to lactate and reproduce by crossing Domiati cattle with them.

(3) In Friesian and Shorthorn trials, direct heterotic effects $\left(\mathrm{H}^{\mathrm{l}}\right)$ are evidenced. Moderate or high estimates of maternal heterosis $\left(\mathrm{H}^{\mathrm{M}}\right)$ in the three trials might indicate that crossbred dams provide better maternal conditions to their daughters than that of purebred dams. The high estimates of $\mathrm{H}^{\mathrm{M}}$ in Shorthorn trial lead to state that crossbred Shorthorn cows resulting from crossbred dams including Shorthorn genes could give more calf crop and longer productive life than those crossbred cows resulting from purebred dams.

\section{REFERENCES}

Arafa, Samira A. 1987. The effect of crossing Egyptian cattle with exotic breeds on some production traits. M.Sc. Thesis, Fac. Agric., Zagazig Univ., Banha Branch, Moshtohor, Egypt, pp 224.

Arafa, Samira A. 1996. Genetic analysis for some productive traits in purebred and graded dairy cattle under the Egyptian conditions. Ph. D. Thesis, Fac. Agric., Moshtohor, Zagazig Univ., Egypt, pp 150.

Arafa, Samira A.; M.H. Khalil; E.A. Afifi and S.M. Zahed 1998. Genetic evaluation of some reproductive performance traits in three up-grading trials of dairy cattle raised in hot climate. Egyptian J. Anim. Prod., 35 (2): 91-108.

Arthur P.F.; M. Makarechian; M.A.Price and R.T. Berg 1989. Heterosis, maternal and direct effects in double-muscled and normal cattle: 1. Reproduction and growth traits. J.Anim. Sci. 67:902-910.

Cundiff L.V.; R.N. Dominguez; G.E. Dickerson; K.E Gregory and R.M. Koch 1992. Heterosis for lifetime production in Hereford, Angus, Shorthorn and crossbred cows. J. Anim. Sci. 70: 2397-2410.

Dickerson G.E. 1992. Manual for evaluation of breeds and crosses of domestic animals. FAO, Rome, pp 47.

Dillard E.U.; O. Rodriguez and O.W. Robison 1980. Estimation of additive and non additive direct and maternal genetic effects from crossbreeding beef cattle. J. Anim. Sci. 50(4): 653-663.

Elzo M.A.; T.A. Olson; W.T. Butts Jr; M. Koger and E.L. Adams 1990. Direct and maternal genetic effects due to the introduction of Bos Taurus alleles into Brahman cattle in Florida. II- Preweaning growth traits. J. Anim. Sci., 68: 324329. 
Gregory K.E.; J.C.M. Trail; H.J.S. Marples and J. Kakonge 1985. Heterosis and breed effects on maternal and individual traits of Bos indicus breeds of cattle. $\mathrm{J}$. Anim. Sci., 60 (5): 1175-1180.

Gregory K.E.; L.V. Cundiff and R.M. Koch 1991. Breed effects and heterosis in advanced generations of composite populations for birth weight, birth date, dystocia and survival as traits of dam in beef cattle. J. Anim. Sci., 69 (9): 3574 3589.

Harvey W.R. 1990

maximum likleihood computer program. PC-Version 2, Ohio State University, Columbus, USA (Mimeograph).

Hohenboken W.B. and D.W. Webet 1989. Crossbreeding among British and Continental European dual-purpose breeds in coastal pacific northwest. J. Anim. Sci. 67 (11): 2841-2847.

Khalil M.H.; E.A. Afifi; M.A. Salem and S.M. Zahed 2000. Estimation of heterotic components for lactation traits and reproductive performance in three crossbreeding trials of Holstein cattle with German Friesian raised under hot climatic conditions. J.Anim. Breed. Genet. 117:129-142.

Koch R.M.; G.E. Dickerson; L.V. Cundiff and K.E. Gregory 1985. Heterosis retained in advanced generations of crosses among Angus and Hereford cattle. J. Anim. Sci., 60: 1117.

Olson T.A.; A.V. Dijk; M. Koger; D.D. Hargrove and D.E. Franke 1985. Additive and heterosis effects on pre-weaning traits, maternal ability and reproduction from crossing of the Angus and Brown Swiss breeds in Florida. J. Anim. Sci. 61 (5): 1121-1131.

Reimer D.; E.M. Kaluba; J.C. Nolan, J.R. and C.M. Campbell 1985. Breeding better beef. 2- Effect of Angus, Hereford, and Santa Gertrudis sires on pre-weaning performance of calves. Research-Extension-Series, Hawaii. AgriculturalExtension-Station, 58, pp 12 .

Thorpe W.; P. Kang ethe; J.E.O. Rege; R.O. Mosi; B.A.J. Mwandotto and P. Njuguna 1993. Crossbreeding Ayrshire, Friesian and Sahiwal cattle for milk yield and pre-weaning traits of progeny in the Semiarid Tropics of Kenya. J. Dairy Sci. 76: 2001-2012.

Trail J.C.M.; K.E. Gregory; H.J.S. Marples and J. Konge (1982). Heterosis, additive maternal and additive direct effects of the Red Poll and Boran breeds of cattle. J. Anim. Sci. 54 (3): 517-523.

Van der Werf, J.H.J. and de Boer, W. 1989a. Influence of non additive effects on estimation of genetic parameters in dairy cattle. J. Dairy Sci., 72: 2606-2614.

Van der Werf, J.H.J. and de Boer, W. 1989b. Estimation of parameters in a crossbred population of Black and White dairy cattle. J. Dairy Sci, 72: 2615-2623.

Wessely E.C.; G. Freyer; J. Biemann; L. Panicke; E. Vetter and H.D.Matthes 1986. Heterosis in dairy cattle breeding. Tagungsbericht, Akademie der Landwirtschaftswissen Schaften-der - Deutschen Demokratischen Republik, No. 240, 35-39. 


\title{
تقدير قيم مكونات الخلط التور اثية لبعض صفات الحياة الانتاجية في تجارب تلرينج الأبة لـر اللامياطي مع ثلاث سلالات ماثبية لبن في مصر
}

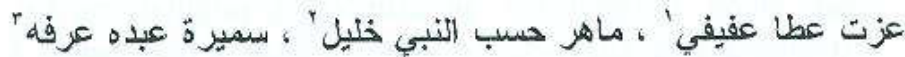

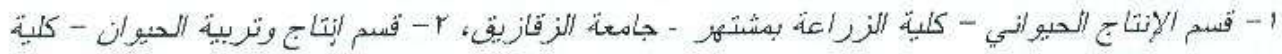

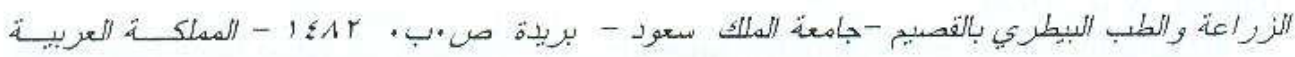

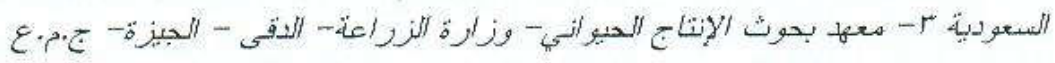

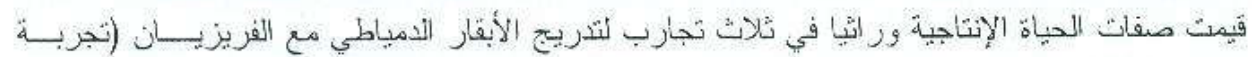

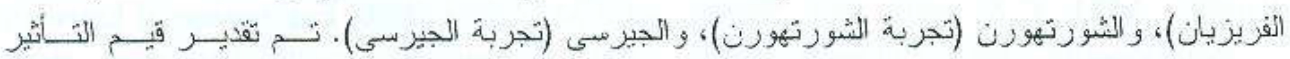

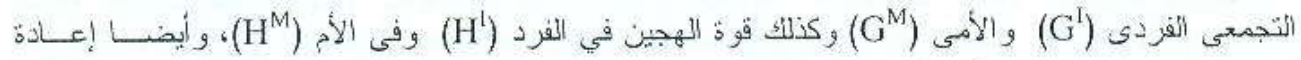

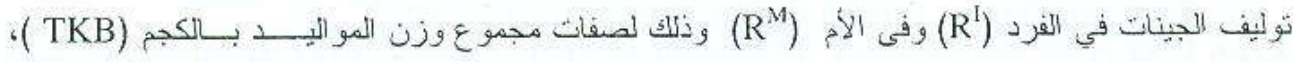

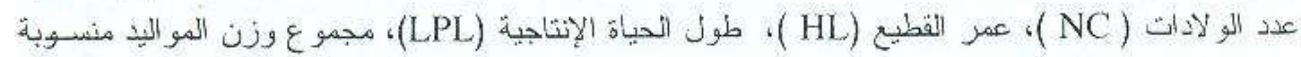
لكل شهر من عمر القطيع) (TKB/HL) وأيضا مجموع وزن المواليد منسوبة لكل شهر من الحياة الإنتاجيسة (TKB/LPL))

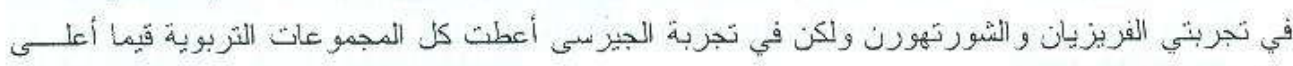

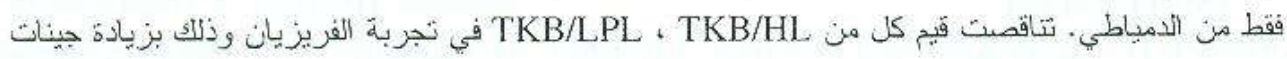

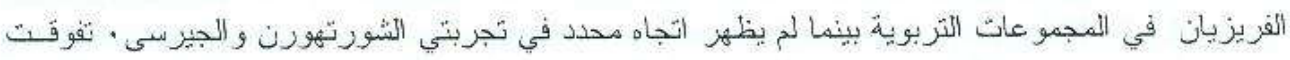

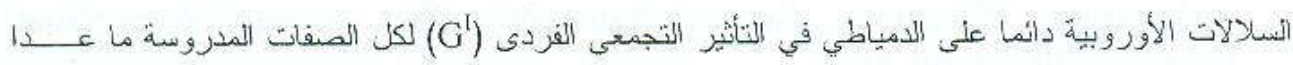

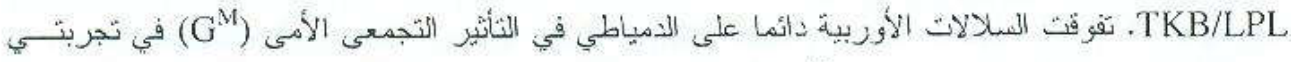

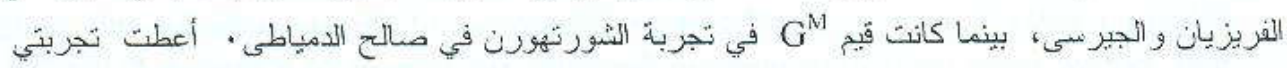

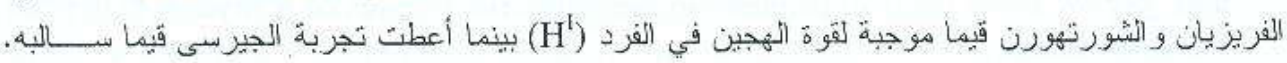

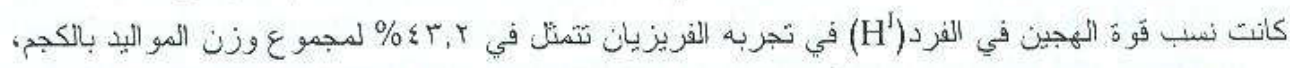

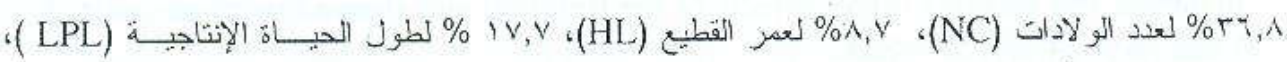

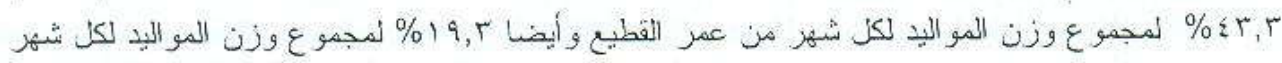

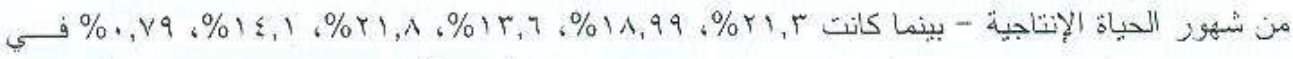

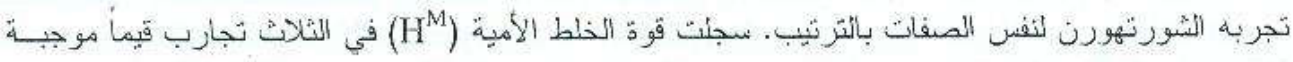

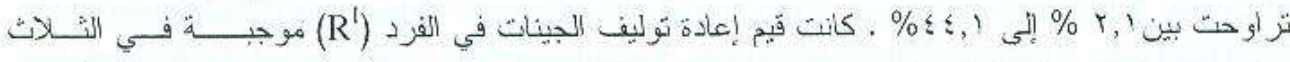

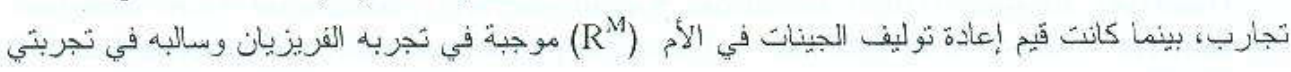

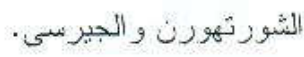

